\title{
From the Playing Fields of Rugby and Eton: The Transnational Origins of American Rugby and the Making of American Football
}

\author{
Adam Burns (University of Wolverhampton)
}

\section{Abstract:}

Some studies date the origins of US intercollegiate football - and, by extension, the modern game of American football - back to a soccer-style game played between Princeton and Rutgers universities in 1869. This article joins with others to argue that such a narrative is misleading, and goes further to clarify the significance of two "international" fixtures in 1873 and 1874, which had a formative and lasting impact on football in the United States. These games, contested between alumni from England's Eton College and students at Yale University, and between students at Canada's McGill University and Harvard University, combined to revolutionize the American football code. Between 1875 and 1880, previous soccer-style versions of US intercollegiate football were replaced with an imported, if somewhat modified, version of rugby football. It was the "American rugby" that arose as a result of these transnational exchanges that is the true ancestor of the gridiron game of today.

Keywords: American football, Eton College, Harvard University, McGill University, rugby, Rugby School, transnational, Yale University

Within a year of its release in 1857, Thomas Hughes' novel Tom Brown's School Days became one of the bestselling books in the United States. ${ }^{1}$ Brown's story is one of an athletic young boy who, through the challenges of life, studies and sporting endeavor at Rugby School in Warwickshire, England, becomes a robust and sporting Christian gentleman. His tale helped bolster the growing cult of "Muscular Christianity" on both sides of the Atlantic, where physicality and morality were increasingly deemed of equal importance in creating truly rounded men. In the post-Civil War (1861-1865) United States, fear that the nation's manly warriors might be replaced by effete intellectuals took root, and many looked to education to arrest such a trend. Just as in England around this time, the attention of many in the United States turned to the nation's schools and colleges as potential nurseries of a new generation of men who were both strong-bodied and spiritually aware. ${ }^{2}$ Athletic team sports, which featured prominently in Hughes' novel, moved rapidly from the margins of US educational life to its very center. 
For many scholars of sports history, public schools (including Rugby) were central to the formation of different footballing codes in England. ${ }^{3}$ However, over the last few decades researchers have begun to question the extent to which public schools should be credited with playing such a fundamental role. For some of these researchers, the roots of Association football (soccer) should be traced to much broader social origins. ${ }^{4}$ Others, meanwhile, have attempted to disprove the quasi-mythical tale behind the supposed innovation of carrying the ball in football at Rugby School, which similarly serves to stress the role of public schools in the history of rugby football. ${ }^{5}$ Whichever side of these debates one finds the more compelling, no one really disputes that English public school alumni or "old boys" (particularly those who went on to the universities of Oxford and Cambridge) played an important role in codifying both Association rules in 1863 and Rugby Union rules in 1871-the two major codes of football at a national level in England. ${ }^{6}$ Yet though the public school origins of English football codes have come under increased scrutiny in recent years, the English public school origins of the predominant footballing code in the United States by the late-nineteenth century are often glossed over.

The early years of football in the United States, like its counterpart codes in England, are often recounted. Just as often, however, accounts of the game's origins and development are confused and obscured. Perhaps the most pervasive narrative in the history of early American football is that of national "exceptionalism"- that football in the US changed rapidly in the last quarter of the nineteenth century to become a more modern, efficient, and distinctly "American" game. ${ }^{7}$ Even those who accept the complications of the term "American exceptionalism," such as Michael Oriard, find this a compelling narrative. ${ }^{8}$ However, in recent years Tony Collins has argued that American football was far from exceptional in its evolution as a distinct code of football. For Collins, before the crucial rule change that allowed for forward passing in 1906 (which he accepts did transform the game beyond recognition), the American game remained a fairly clear adaptation of English rugby union. ${ }^{9}$ A little like the debates over the histories of soccer and rugby in England, the debate over the origins and evolution of American football is an ongoing one.

During the mid-nineteenth century, various hybrid and homespun football codes were in use across the United States, with matches often played under compromise rules to allow for competitions to take place within, among or outside of schools and universities. ${ }^{10}$ However, it was the nation's most 
prestigious higher educational institutions that ended up establishing the code that would, first and foremost, allow them to play each other, and then go on to sweep across the nation during the latenineteenth century. The Princeton-Rutgers football match of 1869 is often cited at the first intercollegiate game in a continuous historical evolution toward the American football of the twentieth-first century. ${ }^{11}$ However, more accurately, the modern gridiron game's origins should be traced to two "international" fixtures. These matches, played between Yale University and Eton College in 1873, and Harvard University and McGill University in 1874, are the focus of this article. It was the transnational code of football that emerged from these two fixtures that is where the chronology of the modern game should begin—whatever one thinks about the game's subsequent evolution and/or exceptionalism. This transnational code, at least until 1880, might more accurately be called "American rugby"—a term occasionally used by the "father of American football" himself, Walter Camp, and also employed in this article. ${ }^{12}$ Though these two international matches have not gone unnoticed by sports historians, the significance of these fixtures in defining a code of football across different US colleges is not always underscored in the available literature. ${ }^{13}$ Where the first fixture is often entirely overlooked, the latter has become something of a staple event used to describe, rather than evaluate, the early days of football. This article seeks to act as a corrective to the many conflicting accounts that skate over this very early phase in football history, and more accurately depict the transnational origins of American rugby.

Firstly, there is a compelling case to be made for the 1873 Eton-Yale football game influencing the later foundation of American rugby by encouraging Yale to push (eventually with success) for an eleven-a-side format then favored by their English opponents. The 1874 McGill-Harvard game, rightly the more noted of the two, transformed Harvard's code of football root and branch. Far from adapting their previous code, Harvard adopted the usually fifteen-a-side rugby game played by their Canadian opponents in totality. By 1880, American rugby - born of these two encounters - was the form of "football" being played by the leading East Coast colleges, and it is this game that evolved into the gridiron game so popular today.

\section{Early-1870s English Public-School Football}


The public schools of Victorian England were the most elite educational establishments in the country. Attended by, among others, the children of the English aristocracy, these schools maintained entrance fees that helped ensure they remained suitably exclusive. Yet, though a growing professional class was increasingly able to gain access and "assimilate," as historian Edward Allen puts it, 'the important and central aspect of the process was the persistent domination of the aristocratic element'. ${ }^{14}$ The nine "Clarendon" schools (as selected for investigation by the Earl of Clarendon's royal commission in the 1860s) were particularly exclusive and included both of the schools most relevant to this article: Eton College and Rugby School. ${ }^{15}$ Between them the Clarendon schools educated only around 3,000 students but, despite their limited intake, their influence was immense in almost every realm of English society, and sport proved no exception. ${ }^{16}$

Though the Clarendon schools shared many characteristics, they often stuck firmly to their own eccentric traditions, and this was never more the case than when it came to games referred to variously as "football". In contrast to rowing or cricket, games of football were originally considered of a lower status in English public schools, largely due to their more chaotic and violent nature. ${ }^{17}$ However, as the pursuit of Muscular Christianity became an increasingly pervasive sentiment in public schools in the middle of the nineteenth century, football and other team sports gained increasing traction. Such sports supposedly not only helped keep the boys ruggedly masculine and prepared them with the team and leadership skills befitting future stewards of the British Empire, but they also aided discipline and order within the schools by allowing a much-needed physical outlet to reduce rebellion and vice. ${ }^{18}$

Though many sports were well established at Eton College by the 1870s, the primary forms of "football" were two bespoke variations: the Field Game and the Wall Game. The 1847 Field Game rule book states that a 'goal' was to be scored by kicking a ball between two 'goal sticks' (and under the sevenfoot height of the sticks). Hands could be used to stop the ball, but 'the ball must not be carried, thrown, or struck by the hand'. ${ }^{19}$ Meanwhile, the Wall Game's 1849 rules were more eccentric (and locally particular), with a 'goal' being scored by kicking the ball against 'the door' or 'the tree' (within the white lines). ${ }^{20}$ For one of the school's nineteenth-century chroniclers, Lionel Cust, they were really just 'different varieties of the same game'. ${ }^{21}$ Though the Wall Game seemed harder to understand, Cust explains, it was 'really the "Field" game played in a narrow space', with its unusual rules accounting for 
the fact there was no room to erect goals. ${ }^{22}$ At Eton, the term "football" was more often attached to the game played 'in the Field' than at the Wall. ${ }^{23}$ Although popular from the early-nineteenth century, the

Field Game had acquired an increasingly respectable place in college life by the late 1860s following the introduction of a 'challenge cup' at the start of that decade. ${ }^{24}$

The code of football played at Rugby School was world famous by the 1860s and 70s, thanks largely to Thomas Hughes' novel, where at one point it is described thus:

You say, you don't see much in it all; nothing but a struggling mass of boys, and a leather ball, which seems to excite them all to great fury, as a red rag does a bull. My dear sir, a battle would look much the same to you, except that the boys would be men, and the balls iron; but a battle would be worth your looking at for all that, and so is a football match. 25

However, the game played at the school by the 1860s had moved on significantly from that depicted in the novel, which, though published in 1857, was set around the 1830s. The earliest rules for Rugby's version of football were codified somewhat later in 1845 and curbed the excesses of these earlier warlike games. For example, rule twenty eight forbade the wearing of 'projecting nails or iron plates on the heels or soles of ... shoes or boots'. ${ }^{26}$ By the 1860s and 70s the game had evolved even further but, most significantly, ball carrying (which was forbidden in Eton's Field Game) was permitted. ${ }^{27}$

For those who support a public-school leadership view of football history, the codification of "Association football" by the Football Association (FA) in 1863 was a defining moment in the ongoing bifurcation between the kicking games played by public schools such as Eton, and the carrying game of Rugby and its allies. ${ }^{28}$ However, although the FA's original game bore some similarities to Eton's Field Game, Eton College itself did not really adopt the Association game as an option until 1894.29 Despite Rugby School's desire to maintain an exclusive game as well, its code became a more clearly "national" one (hence the name), spreading through former staff and alumni across public schools until the Rugby Football Union (RFU) was formed in 1871. By the mid-1870s the FA and the RFU existed as rival football governing bodies in England, albeit with rules still in a considerable amount of flux, while numerous distinct codes persisted across the Clarendon schools themselves. It was in this context that elements of the Eton and Rugby codes made their defining mark in the United States. 


\section{Early 1870s US College Football}

Walter Camp would have fitted nicely into the mold of an English public schoolboy in the 1870s. He attended one of the oldest schools in the United States, established centuries earlier by an alumnus of one of the Clarendon schools. ${ }^{30}$ Hopkins Grammar was not one of the best known in the country, but it echoed the focus on a rounded curriculum with a good dash of team sports favored by leading public schools in England. ${ }^{31}$ As a result of his own strenuous efforts in training and bodybuilding, Camp soon became a leading footballer at his school. ${ }^{32}$ Hopkins Grammar was also a near neighbor of Yale University, where Camp would enroll in 1876 and play a formative role as both an American rugby player and later as a coach and rule maker. Over the years that followed, Camp also became a historian, writing numerous articles and book chapters on the history of football in the United States and helping solidify his place within it.

In 1896, Camp and Lorin Deland, a fellow coach and football influencer (though, at Harvard), put together a brief history of football. When dealing with Yale, the book begins by describing an early version of football, existing from the 1840s until the final match between the classes of 1860 and 1861. It describes such fixtures as more akin to 'open riots' or 'annual rushes', rather like the violent game depicted in Tom Brown's School Days. ${ }^{33}$ After the final match, the game was outlawed for its brutality, and thence came a decade when football was 'practically dead at Yale'. ${ }^{34}$ For Camp, however, these early collegiate brawls were not "football" at all. Indeed, he argues that in the US, nothing 'could be defined by the name of foot-ball until the early 70's. Then there was a game played unlike anything that prevailed in other countries, but which had something of the characteristics of the Association game'. ${ }^{35}$

The renaissance of football at Yale in the early 1870s as a "soccer-style" game is often credited to David Schley Schaff (Class of '73). Schaff, who went on to become president of the Yale Football Association (established in October 1872), had attended Rugby School before his time at Yale, albeit only for one year. ${ }^{36}$ However, if Schaff harbored any desire to implant a game more akin to rugby than soccer, there is no evidence of this. When Schaff appointed a rules committee to codify football for all Yale matches, the result was a game that included rule number five: 'No player shall throw or carry the ball. Any violation of this regulation shall constitute a foul'. ${ }^{37}$ Far from establishing a game comparable to that 
of his Rugby School days, Schaff oversaw the embedding of a game that expressly prohibited one of rugby football's most distinctive features.

On October 18, 1873, Yale players met with representatives from Princeton and Rutgers universities at the 5th Avenue Hotel in New York to establish an intercollegiate association. Harvard had been invited but, in the Yalie author's words, 'for one or two very poor reasons, refused to enter into the plan'. ${ }^{38}$ Columbia University's delegates also missed the gathering, but this was because they were not notified about a change of meeting time. ${ }^{39}$ The rules that those who did attend outlined were similar to Yale's pre-existing ones, stating that 'No player shall throw or carry the ball'.40 This freshly codified intercollegiate game saw first light on October 25, 1873, in a twenty-a-side game at Yale against Rutgers. Soon after, on November 15, Princeton traveled to Yale, further embedding the new system. ${ }^{41}$ By the end of 1873 , the football played in most elite US colleges was a primarily kicking game played by far more than eleven men on each side.

As at Yale, football at Harvard before the Civil War was more of an annual melee, or set of fights, where players competed 'blow for blow, kick for kick' in some cases with one hundred-a-side. ${ }^{42}$ Also like their rivals, Harvard saw football banned. In 1860, in Cambridge, Massachusetts, a satirical funeral ceremony was held to bury the football. ${ }^{43}$ Football was relaunched at Harvard in the spring of 1871 when three students approached President Charles Eliot to request that the game be permitted once more. The game that was introduced was a kicking-centric game played with a round ball. ${ }^{44} \mathrm{Often}$ referred to as the "Boston game," it looked like something of a hybrid between the English FA and RFU codes: a player was allowed to carry the ball, but 'only if pursued by an opponent, and [was] required... to pass or kick it the instant his pursuer abandoned him'. ${ }^{45}$ In many senses, the sort of football being played in 1873 - in both its Yale and Harvard forms - was far more distinctly home-grown and "American" than the American rugby game that took off thereafter.

\section{The Two "International" Games}

On December 6, 1873, the 'first international episode in [North American] football' took place in New Haven, Connecticut, between teams billed as Eton and Yale. ${ }^{46}$ The Eton team that played Yale at 
Hamilton Park was not made up of students, however, but alumni-Old Etonians (OEs). ${ }^{47}$ It was an OE who proposed the idea when he turned up to watch Yale play Columbia, only for that match to be cancelled. ${ }^{48}$ The team comprised nine OEs, one rogue Harrow alumnus, and Viscount Tarbat (a replacement for another OE, the Earl of Rosebery). ${ }^{49}$ While many of the OEs were visiting the US, some were already residents. For example, George Allen and his younger brother Philip were both resident in New York, and Constantine Benson had established a career as a banker in St. Paul, Minnesota. ${ }^{50}$ Aside from a viscount, the rest of the group was made up of those destined to become, variously, members of parliament, justices of the peace, military officers, and the unfortunate Henry Russell who was accidentally killed on a hunting expedition a little over two years later. ${ }^{51}$ The visiting OEs were also accompanied by a number of ladies for the day, and when their train arrived at $12.30 \mathrm{pm}$ they were taken for dinner by their hosts, a sign of the wider social occasion that the fixture was intended to be. ${ }^{52}$

The game the two teams played was a typical compromise, given that a solid set of rules familiar to both did not exist—as one Yale newspaper reporter put it: ' $[\mathrm{t}]$ he rules used by Eton are entirely different to those of ours; they allow no lurking or touching with hands; in short, nearly every point is essentially different'. ${ }^{53}$ The match (made up of three "games") was broadly played to Yale rules, with the exception of some complexities (such as Yale's offside rule) and without Yale's usual twenty players. ${ }^{54}$ As an accommodation to the visitors, the adoption of an eleven-a-side format was made, being both more familiar to the Old Etonians and more achievable given they had a more limited pool of players. ${ }^{55}$ There was a brief warm-up before the match, where the Yale team was briefly taken aback by the Old Etonians dressed in 'the prettiest costume that we ever saw on a foot ball field'. ${ }^{56}$ The match itself was then 'hotly contested', but it seems that the Yale team's superior fitness, wind advantage, and familiarity with one another, were enough to allow them to overcome the visitors: the game ended with a home victory of two goals to one..$^{57}$ Time also played a role, as most of the visiting OEs had a train to New York they needed to catch, and the game was ended to allow them to make it to the station in good time..$^{58}$ According to the Hartford Courant, the game 'was heartily enjoyed by the spectators', while the Brooklyn Union called it a 'first-class sensation'. ${ }^{59}$ For one Yale reporter, it was surely the 'most interesting match of the year, and the one in which our eleven took more satisfaction than in any game that they have ever played'. ${ }^{60}$ 
Eugene Baker, a Yale player on the day, noted the freedom of play that the eleven-a-side game with Eton allowed for. ${ }^{61}$ He later went on to captain Yale's American rugby team in 1876, a squad that included the young Walter Camp. Only days after the Eton-Yale football match, the Yale Record published a lengthy report on how this clash might inspire changes to Yale's existing game. Among these, it pointed

to the eleven-a-side factor:

Now that the last game of foot ball for this year has been played, and the new rules have been subjected to a fair test, we should like to say a few words about some defects which have been found in them. In the first place, we think that a smaller number of players would be a good change. Those persons who were present at the Eton-Yale game know with how much more pleasure they watched the playing than when there are twenty on a side. ${ }^{62}$

Whether the OEs were most familiar with the Field Game from their time at school, or might have dabbled with the Association game at some point afterwards, it was the OE match that clearly popularized the eleven-a-side concept at Yale. For Yale player, William O. Henderson, the Eton-Yale game was not only 'the first game, after the revival of football, in which a Yale team was composed of eleven players only', it represented a more momentous occasion:

This event has had a lasting influence upon the American game, because, in the subsequent conference between the representatives of the associated colleges as to terms and methods of play, Yale carried and established her point that the then new so-called Rugby game should be played with eleven men only on a team. Thus, the American Rugby game became and is the original Rugby game played by the Eton number of players. ${ }^{63}$

Though the Etonian influence on Yale was direct but relatively limited (relating to the number of players on each side), the impact of Rugby School's code of football was indirect but with a transformative impact on US football. It was not current Rugbeians that traveled to the US, nor - unlike the OEs at Yale - was it a squad of Rugby School alumni. Instead Rugby School's game came via imperial links with the recently confederated Dominion of Canada (formed in 1867), just over the border. Particularly important in disseminating the game in Canada were British army garrisons and Canadian private schools. The garrison officers and students possessed the time and money to take part in sports for leisure, and the officers brought with them experience of English public schools and their various sporting traditions. ${ }^{64}$ Alan Metcalfe suggests that, 'Sport [in Canada] was moulded in the image of the English aristocracy and was transmitted to young, native-born children in private schools that were unashamedly British in origin and focus'. ${ }^{65}$ By 1874 , the game of Canada's elite was not all that far removed from its relatively recent British roots. 
It was the nation's largest city, Montreal, that became the hotspot for organized sport in Canada. Despite its large Francophone population, the organization of sport in the city remained a primarily Anglophone affair — the city being home to its fair share of garrisons, imperial businesses and Englishspeaking private schools. ${ }^{66} \mathrm{McG}$ ill University in Montreal was thus uniquely poised to become a bastion of Canadian sporting codification: an Anglophone, elite educational establishment in the metropolitan and sporting heart of post-Confederation Canada. According to Dr R. Tait McKenzie, a former McGill student and athlete, it was McGill University that can be credited with involvement in the first rugby game in Canada. ${ }^{67}$ In 1865, McGill students and graduates comprised the bulk of a team formed to take on a side of British troops garrisoned in Montreal. ${ }^{68}$ Montreal can also claim the first organized rugby club in the country: the Montreal Football Club (MFBC), though the team played both rugby and Association football depending on its opposition. Formed in 1868, the MFBC relied upon army games for sustenance to begin with. ${ }^{69}$ However, soon enough, two more clubs had formed: the Britannia Club and McGill, allowing for popular "town versus gown" matches. ${ }^{70}$

In the spring of 1872, the year after the Rugby Football Union was formed in England, the Quebec provincial sides formed the "Dominion Foot Ball Association," maintaining what became a persistent use of the catch-all term "football" to describe many different codes in North America. The MFBC, which swiftly became the side to beat, then offered up a "challenge cup" to encourage competition from outside of the city. In 1873 the MFBC defeated Quebec [City] in their first cup game. ${ }^{71}$ That evening, in a sign of the elite and social nature of the sporting contest, the MFBC entertained their guests at the prestigious Carlton, which, according to the university's student paper, left the visitors 'well satisfied with their treatment, if not with the result of the match'. ${ }^{72}$ McGill students trained alongside the MFBC players during the following season, but talk of an intercollegiate competition was growing. ${ }^{73}$

Down in Massachusetts, Harvard students also began to yearn for some intercollegiate football competition. However, the clashing codes of its elite northeastern peers meant this was still an unlikely proposition—as one Harvard footballer of the era put it: 'Correspondence ... developed such irreconcilable differences in the rules that no common ground of agreement could be found'. ${ }^{74}$ Students in Montreal, reading of this in one of Harvard's student newspapers, the Advocate, felt that McGill might get involved in some such affair in the US, and 'show that the being on a different side of a boundary line 
from most of the competitors does not interfere with the development of strength or swiftness' ${ }^{75}$

Indeed, the growth of athletics and the spirit of competition at McGill spurred one student to speak of 'a spirit of muscular Christianity' asserting itself among the student body. ${ }^{76}$

Despite their mutual interest in playing intercollegiate football, a US-Canadian match would still prove challenging. Though McGill students sought out the rules of the football games played by Yale and Harvard, in anticipation of an international intercollegiate fixture, they also knew that the stumbling block was that 'we ourselves play the Rugby game, which differs in toto from the game played at these colleges'. ${ }^{77}$ In April 1874, McGill reciprocated the earlier favor of Harvard and Yale and published its "rugby rules" in the college newspaper. ${ }^{78}$ It was around this time also that McGill's rugby captain, David Rodger, wrote to Harvard's captain, Henry Grant, proposing a series of matches—one in Montreal and one in Cambridge. One would be a game of rugby and one a game of Boston football. Harvard player William R. Tyler recalled that, 'We felt that our country's honor was in our hands, and we accepted'.79 In the end, the teams agreed to play both matches in Cambridge, but retained the provision that one game be played according to Harvard rules and one on McGill's 'own terms' and after their 'own fashion'. 80

On April 25, the McGill side held a practice game of rugby on the College Grounds in Montreal, and lost. ${ }^{81}$ The warm-up result did not bode well for their prospects in Cambridge. However, bad weather and a 'lack of experienced coaching' meant they had hardly an 'inkling' of the Harvard game. Meanwhile, in Cambridge, 'much coaching and faithful work', according to player William Tyler, made the US team increasingly familiar with rugby's 'egg-shaped ball', drop kicks, and different off-side rules. ${ }^{82}$ The day before the first match, mixed sides of Harvard and McGill students practiced together to try and develop a better understanding of one another's codes. They then contested their first formal match (made up of three "games") under Harvard rules on Thursday May 14, 1874.83 Though the Boston game was somewhat closer to rugby than the form of football played by its primary northeastern rivals, it was distinct enough to entirely confound the visiting team. According to Harvard's student paper, The Magenta, the game was 'a disappointment to all who saw it'. Harvard romped to a virtually uncontested victory thanks to countless infringements from the hapless McGill players. For the student reporter at Harvard, it seemed the spectators were almost as involved as the McGill players during this debacle of a 
contest. ${ }^{84}$ However, the fact that the first game fell so flat with both players and spectators only added

greater verve to the contest that followed on Friday.

[Insert Figure 1 here]

Figure 1. "Harvard versus McGill, 1874," HUPSF Football (BP22), olvwork654259.

Harvard University Archives

The second match (again of three "games"), played to McGill's rugby rules, had the potential to be a repeat of Thursday's rout but in the opposite direction. ${ }^{85}$ The one variation being that both sides agreed to play with twelve men on each side, rather than McGill's regular fifteen-a-side rugby game, since McGill had failed to bring enough players. ${ }^{86}$ The Harvard men, of course, were only slightly better versed in rugby than the McGill players were in the Boston game. The very appearance of the Canadians, 'dressed in their English football suit', seemed to exude competence in contrast to the 'shabby looking' men of Harvard in their magenta bandanas. Yet Harvard proved adept enough - and rough enough - to salvage a draw in a fiercely contested game that had been the assumed prize of the visitors. The Boston Globe reported that at times the rugby game had proved 'intensely exciting', while the Boston Post noted there was a 'large crowd and much enthusiasm'. ${ }^{87}$ Despite the lack of any scoring, the rugby game was deemed a hit, and the Magenta reporter hoped for 'several games' to come in the future. ${ }^{88}$ Meanwhile, the Advocate predicted that 'Football will be a popular game here in the future. The Rugby game is in much better favor than the somewhat sleepy game now played by our men'. ${ }^{99}$ Much hospitality was still to be enjoyed by the visiting McGill men at Harvard's clubs and a champagne-fueled banquet at Parker's in Boston, but the stage had been set for a revolution in football in the United States. ${ }^{90}$

\section{The Success of American Rugby and the Making of American Football}

Though the prospect of future games with McGill had some appeal to Harvard students, the real hunger among both players and spectators was for a clash with their nearer rivals, and none more so than Yale. Though McGill gradually fell out of favor as opponents over the next few years, their game was adopted wholesale by Harvard soon after the 1874 meeting. With Harvard playing rugby instead of Boston 
football, they were in much the same position as before in terms of being the oddest one out when it came to football codes in the northeastern United States. However, instead of the relatively dull homespun version of Boston football that even many in Harvard did not like, they now had a more attractive game with which to entice their regional rivals, as well as the draw of being the nation's oldest and most famous university. For some historians, Harvard was attracted to rugby for its elite distinctiveness, something which marked it out from the more widely played soccer in England and would therefore mark it out similarly from other codes in the United States. ${ }^{91}$ However, if they were to make an intercollegiate game of it in the US, they would need to convert other prestigious colleges.

On October 16, 1875, the Yale and Harvard captains met in Springfield, Massachusetts, to decide upon a compromise code to enable Yale-Harvard matches to take place. As Walter Camp later described it, Yale and Harvard's intention 'to harmonize the Association and Rugby games', was something 'even the venturesome American was hardly capable of accomplishing' ${ }^{92}$ What they agreed upon were 'modified Rugby Rules' and the first match took place on November 13, 1875. In the eyes of the Yale players, Harvard had a big advantage, on account of the fifteen-a-side rugby game being far more familiar to the Cambridge men and, as a result, Yale slumped to a four goal and two touchdown to nil defeat. ${ }^{93}$ The battle to get Harvard to concede to eleven-a-side would continue for several years, though rugby rules looked set to stay at Yale.

A year later, on November 23, 1876, representatives from Harvard, Columbia and Princeton created a new Football Association, which Yale refused to join. ${ }^{94}$ Even though Yale had now adopted rugby (or an eleven-a-side version of it), Harvard encouraged the other Association members, Princeton and Columbia, to stick with fifteen-leading to the cancellation of several matches at the start of the 1877-78 season. Yale instead played Tufts, Trinity College and the Stevens Institute of Technology, before finally backing down and playing fifteen-a-side against Princeton—a match that saw Walter Camp score the first touchdown in a two touchdown to nil victory for Yale. ${ }^{95}$ The start of the 1878-79 season saw Yale, Princeton and Harvard meet to try and overcome the impasse over the "fifteen or eleven-aside" debate, with Yale once again conceding a temporary and reluctant defeat. ${ }^{96}$ Despite Yale's continued frustration at playing with fifteens, they overcame Harvard on the Boston baseball grounds in November 
1878 by one goal to nil, with one Yale player, somewhat lacking in modesty, describing their victory as down to 'superior playing on every point of the game'. ${ }^{97}$

Finally, at the start of the 1880-81 season, the "fifteen or eleven" debate was ended at a meeting between Harvard, Princeton, Columbia and Yale at Massasoit House in Springfield, Massachusetts, on October 13. According to the account of Yale's Football Association president: 'The number of players was reduced from fifteen to eleven; Harvard opposing the change, while Princeton opposed the admission of Columbia. Numerous and important changes were made in the rules, with the purpose of making the game less rough, more scientific and of more interest to the spectators'. ${ }^{98}$ Between them Harvard and Yale had ultimately both managed to put their stamp onto American rugby. Yale had succeeded in pressing for an eleven-a-side game and Harvard had provided rugby rules. In both cases, these innovations could be seen as entirely imported, in different ways, from English public schools via transnational elite networks. Such clear lines of travel certainly add support to the arguments of scholars, such as Tony Collins, who have questioned the exceptionalism of American football in recent years. ${ }^{99}$

However, the major colleges not only switched to eleven-a-side in 1880, they also agreed various other rule changes. Among these was the abolition of a recognizable rugby "scrum" and the adoption of the "snapback" (with the feet). For some scholars, this was the end of American rugby and the beginning of a truly distinct new game of American football. ${ }^{100}$ Camp's voluminous writings would attest that, from at least this point onward, the US game evolved to become more efficient, well-ordered and distinctively American. ${ }^{101}$ For Camp this was 'made necessary by the lack of any existing foot-ball lore or tradition on American soil. The English game was one of traditions'. ${ }^{102}$ However, Camp's writings also show that he considered the game of his adulthood 'an out-growth or development of the English Rugby foot-ball game'. ${ }^{103}$ Though Camp's written works give an overview of the numerous further rule additions and excisions after 1880, in 1893 he conceded that the American game still bore 'a striking resemblance' to the game of the RFU. ${ }^{104}$ For him, the vital difference remained that between English rugby's scrummage and the American game's scrimmage—concluding, '[i]n other respects, with the exception of greater liberties in assisting a runner, it would not be very difficult to harmonize our game with the British'. ${ }^{105}$ Even the father of American football was not wholly emphatic about the exceptionalism of the American game by the end of the century. 
In 1873 and 1874, the two international games played by Yale and Harvard with the Old

Etonians and McGill University initiated a rapid transition away from the diverse football scene of the

preceding years. Whereas beforehand a primarily kicking, non-carrying game appeared to be prevailing, by

1875 rugby had triumphed as the code to be taken forward by the US college elite. It was this

transnational code that would later evolve into one of the most popular sports in the nation. Added to

this, with the persistence of Yale in resisting wholesale acceptance of Harvard's imported rugby game, the

fingerprints of Eton's eleven-a-side game were also evident after the compromises of 1880 . Though the

game still had a long way to travel after 1880 toward its current form, its roots are very clearly in those

two "international" fixtures of 1873 and 1874. By taking a closer look at these two matches and their

consequences, this article helps not only highlight the formative role of these encounters in the creation

of "American rugby," but also their central place in the broader history of American football. In so doing,

it demonstrates the very clear transnational exchanges that initiated the formation of a code of football

enjoyed by millions of Americans to this day. ${ }^{106}$

${ }^{1}$ Roberta J. Park, "Sport, Gender and Society in a Transatlantic Victorian Perspective," International Journal of the History of Sport 24, no. 12 (2007): 1570-1603, (esp. 1573).

2 Dieter Petzold, "Breaking in the Colt: Socialization in Nineteenth-Century School Stories," Children's Literature Association Quarterly 15, no. 1 (1990): 17-21, (esp. 18).

${ }^{3}$ The "ownership" of English football remains hugely contentious among sports historians. For the famous argument that elite schools lay at the heart of forging "modern" football codes, see Eric Dunning and Kenneth Shard, Barbarians, Gentlemen and Players, 2nd edition (Abingdon: Routledge, 2005).

${ }^{4}$ Peter Swain, "Football Club Formation and the Lancashire Leisure Class, 1857-1870," International Journal of the History of Sport 34, nos. 7-8 (2017): 498-516, and Peter Swain and Adrian Harvey, "On Bosworth Field or the Playing Fields of Eton and Rugby? Who Really Invented Modern Football?" International Journal of the History of Sport 29, no. 10 (2012): 1425-1445. For an overview of the main debate, see Adrian Harvey, "The Emergence of Football in Nineteenth-Century England: The Historiographic Debate," International Journal of the History of Sport 30, no. 18 (2013): 2154-2163;

${ }^{5}$ For one recent effort, see Lincoln Allison and Rusty MacLean, “There's a Deathless Myth on the Close Tonight: Re-assessing Rugby's Place in the History of Sport," International Journal of the History of Sport 29, no. 13 (2012): 18661884.

${ }^{6}$ Matthew Taylor, The Association Game: A History of British Football (Abingdon: Routledge, 2013), 24.

7 Among those that follow, at least broadly, the view that American football developed due to cultural particularism and/or conscious nationalistic design are: David Riesman and Reuel Denny, "Football in America: A Study in Culture Diffusion," American Quarterly 3, no. 4 (1951): 309-325; Andrei S. Markovits, "The Other 'American Exceptionalism': Why is There No Soccer in the United States?” International Journal of the History of Sport 7, no. 2 (1990): 230-264; Andrei S. Markovits and Steven S. Hellerman, Offside: Soccer and American Exceptionalism (Princeton, NJ: Princeton University Press, 2001), and S. W. Pope, Patriotic Games: Sporting Traditions in the American Imagination, 1876-1926 (New York: Oxford University Press, 1997). A similar debate took place early in the twentieth century in relation to baseball. Sportswriter Henry Chadwick claimed that the game's roots might be found in the English game of rounders, but an official commission set up by Albert G. Spalding decided in 1908 that the game was decidedly an American creation, see: John Thorn, Baseball in the Garden of Eden: The Secret History of the Early Game (New York: Simon \& Schuster, 2011), xii.

${ }^{8}$ Michael Oriard, Reading Football: How the Popular Press Created an American Spectacle (Chapel Hill: University of North Carolina Press, 1993), 27. 
9 See especially Tony Collins, "Unexceptional Exceptionalism: The Origins of American Football in a Transnational Context," Journal of Global History 8, no. 2 (2013): 209-230, and Tony Collins, How Football Began: A Global History of How the World's Football Codes Were Born (Abingdon: Routledge, 2018).

${ }^{10}$ Brian D. Bunk, "Football Outside the Schools in the United States before Codification," in The Early Development of Football: Contemporary Debates, ed. Graham Curry (New York: Routledge, 2019), 11-25.

${ }^{11}$ Raymond Schmidt, Shaping College Football: The Transformation of an American Sport, 1919-1930 (Syracuse, NY: Syracuse University Press, 2007), 8, situates the origins of 1920s gridiron football in the intercollegiate matches that followed the Princeton-Rutgers game of 1869. This is indicative of a wider tendency to confusingly merge the sort of soccer-style game played in New Jersey in 1869 with the rugby imported from Canada in 1874. For a description of the Princeton-Rutgers game, see Ronald A. Smith, Sports and Freedom: The Rise of Big-Time College Atbletics (New York: Oxford University Press, 1988), 69-70.

12 The term "father of American football" has become fairly widespread, and has been for some time. For example, it is the subtitle of Harford Powel, Jr.'s, Walter Camp: The Father of American Football, A Biography (Boston: Little, Brown \& Co., 1926). For the term "American rugby," see Chapter 1 "English and American Rugby," in Walter Camp, American Football, revised edition (New York: Harper \& Brothers, 1893), 1-21.

${ }^{13}$ For example: Allison Danzig, The History of American Football: Its Great Teams, Players and Coaches (Englewood Cliffs, NJ: Prentice Hall, 1956), 9-10, notes both games, but goes no further; Mark Bernstein, Football: The Ivy League Origins of an American Obsession (Philadelphia, PA: University of Pennsylvania Press, 2001), 10, gives only one paragraph to the McGill-Harvard game and does not mention the Eton game; David M. Nelson, The Anatomy of a Game: Football, the Rules, and the Men Who Made The Game (Newark, NJ: University of Delaware Press, 1994), 32, gives only one paragraph each to these two important fixtures; and Gerald R. Gems, For Pride, Profit and Patriarchy: Football and the Incorporation of American Cultural V alues (Lanham, MD: Scarecrow Press, 2000), 13, mentions both games briefly. In contrast, Smith, Sports and Freedom, 74-75 and 77, gives more space to the McGill-Harvard game, but no direct account of the Eton game. He does, however, note Yale's determination to play eleven-a-side as being linked to the Eton fixture, though he suggests it was primarily down to convincing faculty to support the game as it would affect fewer students.

${ }^{14}$ Edward A. Allen, "Public School Elites in Early-Victorian England: The Boys at Harrow and Merchant Taylors' Schools from 1825 to 1850," Journal of British Studies 21, no. 2 (1982): 87-117.

15 The others were: Charterhouse, Harrow School, Merchant Taylors' School, Shrewsbury School, St. Paul's School, Westminster School and Winchester College.

${ }^{16}$ Colin Shrosbree, Public Schools and Private Education: The Clarendon Commission, 1861-1864 and the Public Schools Act (Manchester: Manchester University Press, 1988), 8.

${ }^{17}$ Kevin Waite, "Beating Napoleon at Eton: Violence, Sport and Manliness in England's Public Schools, 17831815," Cultural and Social History 11, no. 3 (2014): 407-424, (esp. 416-17). Waite also notes this sort of early football's folk (popular) origins, and this factor would only have added to the disdain with which many public schools regarded the sport.

18 Tony Collins, A Social History of English Rugby Union (New York: Routledge, 2009), 10; J. A. Mangan, Athleticism in the Victorian and Edwardian Public School: The Emergence and Consolidation of an Educational Ideology (Cambridge:

Cambridge University Press, 1981), 22-30.

${ }^{19}$ Field Book, 1847, pp. 6 and 10, in SCH/SP/F1/1/1, Eton College Archives, Eton, Berkshire (hereafter ECA).

Rules 8 and 22.

${ }^{20}$ F. E. Stacey and W. R. Coleridge, The Wall, 1849, n.p., in SCH/SP/MW/1, ECA, Rule 18.

${ }^{21}$ Lionel Cust, $A$ History of Eton College (New York: Charles Scribner's Sons, 1899), 247.

22 Ibid., 248.

${ }^{23}$ H. C. Maxwell Lyte, A History of Eton College, 1440-1910, 4th edition (London: Macmillan, 1911), 322.

${ }^{24}$ Ibid., 322 and 561 (quote 322).

25 Thomas Hughes, Tom Brown's Schooldays, edited by Andrew Sanders (Oxford: Oxford University Press, 1999), 105106. In many earlier editions of the novel, the term "school days" is used instead of "schooldays," which is the convention followed in this article.

${ }^{26}$ Football Rules (Rugby: J. S. Crossley, 1845) [facsimile], in box labelled "Football," 371.84796333, Rugby School Archives, Rugby, Warwickshire (hereafter RSA), 15.

27 The roots of carrying in rugby have been debated extensively, to the extent that the much-heralded origin storyinvolving Rugby schoolboy William Webb Ellis innovating by picking up and carrying the ball during a game-has been widely dismissed as a myth. Early studies of the game's origins include the detailed, Old Rugbeian Society, The Origin of Rugby Football: Report (with Appendices) of the Subcommittee of the Old Rugbeian Society, Appointed in July 1895

(Rugby: A. J. Lawrence, 1897). For most, the only real "proof" of Webb Ellis inventing the game comes from a far later account of a game that took place in 1823, given by Matthew Bloxham. See Matthew Holbeche Bloxham, "Rugby School Football Play" [clipping], in box labelled "Football" 371.84796333, RSA.

28 Taylor, The Association Game, 29-30. For Taylor, this group is headed by Eric Dunning. As Collins, Social History of English Rugby Union, 14-15, notes, this is despite the fact the FA's original rules allowed for handling of the ball (though not carrying) and Rugby School alumni had a significant hand in shaping these rules. 
${ }^{29}$ Lyte, History of Eton College, 562. Many Etonians went on to play football at university (where they played under compromise codes used to allow different public-school alumni to play together), while a few then went on to play in FA teams such as the Old Etonians FC.

${ }^{30}$ Hopkins Academy, History of the Hopkins Fund, Grammar School and Academy in Hadley, Mass., 1657-1890 (Amherst, MA: Amherst Record Press, 1890), 5-6.

${ }^{31}$ Julie Des Jardins, Walter Camp: Football and the Modern Man (New York: Oxford University Press, 2015), 16.

32 Robert Tamte, Walter Camp and the Creation of American Football (Urbana: University of Illinois Press, 2018$), 10$.

33 Walter Camp and Lorin F. Deland, Football (Boston: Houghton, Mifflin \& Co., 1896), 16.

${ }^{34}$ Camp and Deland, Football, 17. The question of the brutality of rugby/football re-emerged in various forms across the next several decades, even if its later forms were less savage (most notably in 1905).

35 Walter Camp, The Book of Foot-Ball (New York: Century Co., 1910), 14.

${ }^{36}$ Camp and Deland, Football, 17; Parke H. Davis, Football: The Intercollegiate Game (New York: Charles Scribner's Sons, 1911), 54-55; Bernstein, Football, 8.

${ }^{37}$ Various, [Yale] Football Association: President's Book, p. 1, in Department of Athletics, Physical Education and Recreation, Correspondence Sports and Data, 1872-84, RU 507, YRG: 38-A, Box 3, Folder (3) 21, Yale University Archives, New Haven, Connecticut (hereafter YUA).

38 Ibid., 7.

${ }^{39}$ Ibid.

40 Ibid. 9-17

${ }^{41}$ Ibid.

42 “The Harvard Foot-Ball Match," Boston Daily Advertiser, c. September 1858 [clipping], in HUD10000 Box 1, Football General Folder, 1858, Harvard University Archives, Cambridge, Massachusetts (hereafter HUA).

43 "Harvard College: The Football Buried in the Delta," Boston Daily Advertiser, September 13, 1860, in HUD10000

Box 1, Football General Folder, 1860, HUA.

${ }^{44}$ Morris A. Bealle, The History of Football at Harvard, 1874-1948 (Washington, DC: Columbia Publishing Co., 1948), 17. Bealle takes details from an early issue of the Harvard Advocate as recounted by one of the three students that approached Eliot, William R. Tyler.

45 Parke H. Davis, “The McGill-Harvard Football Game of 1874,” Harvard Alumni Bulletin, March 15, $1916,453$.

${ }^{46}$ Clarence Deming, Yale Yesterdays (New Haven, CT: Yale University Press, 1915), 220.

${ }^{47}$ Not to be confused with the FA team, Old Etonians FC.

48 "Foot Ball," Yale Record, December 10, 1873, 167-168.

49 "Football in America," Bell's Life in London and Sporting Chronicle, January 3, 1874, 9. See also "Eton/Yale, Foot Ball Match" [program], in MISC OEFC 3/1, ECA.

${ }^{50}$ Players listed in "Eton/Yale, Foot Ball Match," and biographical sketches from The Eton Register, Part III: 1862 1868 (Eton: Spottiswoode \& Co., 1906), 40, 76 and 90.

${ }^{51}$ Eton Register, Part III, 3, 10, 13, 38, 43, 73, and 76.

52 Deming, Yale Yesterdays, 220; "Foot Ball," Yale Record, December 10, 1873, 168.

53 "On the Campus," Yale Record, November 26, 1873, 152.

${ }^{54}$ Deming, Yale Yesterdays, 220; "Foot Ball," Yale Record, December 10, 1873, 168.

55 "Football in America," Bell's Life in London, January 3, 1874, 9.

56 "Foot Ball," Yale Record, December 10, 1873, 168.

57 "Football in America," Bell's Life in London, January 3, 1874, 9.

${ }^{58}$ Deming, Yale Yesterdays, 221.

59 "Yale Notes," Hartford Courant, December 9, 1873, 4; "Foot Ball," Brooklyn Union, December 8, $1873,3$.

60 "Foot Ball," Yale Record, December 10, 1873, 168.

${ }^{61}$ Tamte, Walter Camp, 12.

62 "Foot Ball," Yale Record, December 17, 1873, 184

${ }^{63}$ William O. Henderson, “Old Football Days," Yale Alumni Weekly, December 30, 1921, 371.

${ }^{64}$ Don Morrow and Kevin B. Wamsley, Sport in Canada: A History, 2nd edition (Oxford: Oxford University Press, 2010), 53.

65 Alan Metcalfe, Canada Learns to Play: The Emergence of Organized Sport, 1807-1914 (Toronto: McClelland \& Stewart, 1987), 30 .

${ }^{66}$ Morrow and Wamsley, Sport in Canada, 50. For more detail on the evolution of sport in Montreal from a sociological perspective see Alan Metcalfe, "Organized Sport and Social Stratification in Montreal: 1840-1901," in Canadian Sport: Sociological Perspectives, eds. Richard S. Gruneau and John G. Albinson (Reading, MA: Addison-Wesley, 1976), 77-101.

${ }^{67}$ R. Tait McKenzie, “Athletics at McGill,” pp. 10-11 in bound manuscript, [n.d., logged under 1909], McGill

University Archives, Montreal, Quebec.

68 Ibid.

${ }^{69}$ Nancy Howell and Maxwell L. Howell, Sports and Games in Canadian Life: 1700 to the Present (Toronto: Macmillan of Canada, 1969), 77. 
${ }^{70}$ McKenzie, "Athletics at McGill," 11. See also, R. Tait McKenzie, "Rugby Football in Canada," Dominion Illustrated Monthly, February 1892, 11-19. The term "town versus gown" refers to non-students versus students.

71 "Foot Ball," McGill Gazette, November 1, 1873, 14. The report makes the rules that were used a little unclear, as it suggests no carrying of the ball was allowed, but refers to "touchdowns" and kicks for goal. It also refers to Association rules, but this likely means the Dominion Football Association (rather than the Football Association in England).

72 Ibid.

73 "Foot Ball," Mc Gill Gazette, January 1, 1874, 32.

${ }^{74}$ William R. Tyler, cited in Bealle, History of Football at Harvard, 18.

75 “A Proposition from Harvard," McGill Gazette, February 1, 1874, 48.

76 "University Athletics," Mc Gill Gazette, February 1, 1874, 52.

77 "Athletic Notes," McGill Gazette, March 1, 1874, 66.

78 "Playing Rules," Mc Gill Gazette, April 1, 1874, 79.

79 Tyler cited in Bealle, History of Football at Harvard, 18. Harvard demurred on traveling to Montreal as they believed that they would not be allowed the time away from their studies, see Morton Prince, "Football at Harvard, 18001875," in The H Book of Harvard Athletics, 1852-1922, ed. John A. Blanchard (Cambridge, MA: Harvard Varsity Club, 1923), 311-371 (esp. 359).

80 "[No headline]," Magenta [later Crimson], March 27, 1874, n.p. [digital], see Harvard Crimson online archive, https://www.thecrimson.com/sitemap/ (accessed November 16, 2019); "Notes on Football," McGill Gazette, April 1, 1874), 78-79.

81 "Football Notes," Mc Gill Garette, May 1, 1874, 99.

82 Tyler cited in Bealle, History of Football at Harvard, 18.

83 The dates were shifted due to a delay in the arrival of McGill's players from Wednesday and Thursday, to Thursday and Friday. However, Davis, "McGill-Harvard Football Game," 451, gets the actual dates confused (Thursday was the 14th in 1874, not the 15th).

84 "The Foot-Ball Match," Magenta, May 22, 1874, n.p. [digital].

85 These rules differed from those of the RFU somewhat, as the Canadians did not divide the game into forty-fiveminute halves, according to Bealle, History of Football at Harvard, 19. Davis, "McGill-Harvard Football Game," 452453, explains that each "match" in this two-match series across the two days, comprised three half-hour "games".

${ }^{86}$ Davis, "McGill-Harvard Football Game," 452-453. The number on each side is stated as eleven in Prince,

"Football at Harvard," 360, though Davis consulted former players in the preparation of his article and feels the players' memories were somewhat untrustworthy on such details.

87 “The Suburbs-Cambridge," Boston Globe, May 16, 1874, 8; “Foot Ball," Boston Post, May 16, 1874, 3.

88 "The Foot-Ball Match," Magenta, May 22, 1874, n.p. [digital].

${ }^{89}$ Cited in Davis, "McGill-Harvard Football Game," 455.

90 Prince, "Football at Harvard, 1800-1875," 364.

${ }^{91}$ Nathan D. Abrams, "Inhibited but not 'Crowded Out': The Strange Fate of Soccer in the United States," International Journal of the History of Sport 12, no. 3 (1995): 1-17 (esp. 7-8).

${ }_{92}$ Camp, The Book of Foot-Ball, 14.

${ }^{93}$ [Yale] Football Association: President's Book, 26-27.

94 Ibid., 29-30.

95 Ibid., 33-35.

${ }^{96}$ Ibid., 37.

${ }^{97}$ Ibid., 41.

98 Ibid., 51.

99 Collins, "Unexceptional Exceptionalism".

100 Many texts present 1880 as the beginning of a truly distinct “American football” game under Camp's guidance.

For example, see the detailed early overview of the game's history in Alexander M. Weyand, The Saga of American

Football (New York: Macmillan, 1955), 21.

101 Oriard, Reading Football, 40-41.

102 Walter Camp, Walter Camp’s Book of College Sports (New York: Century Co., 1893), 88.

103 Ibid.

104 Quote from Camp, Book of College Sports, 90; for a more detailed overview of rule developments, see Chapter 1 in Camp, American Football.

105 Camp, Book of College Sports, 91.

${ }^{106}$ Many thanks to the British Association for American Studies' Early Career Short-Term Travel Award, the Rothermere American Institute at the University of Oxford's Vacation Visiting Research Fellowship and the Centre for Historical Research at the University of Wolverhampton for helping support the research that went into this article. Thanks also to participants at the 2019 British Society of Sports History and British American Nineteenth Century Historians conferences for their feedback on earlier versions of this paper. I would also like to acknowledge the invaluable help of the following archivists: Eleanor Hoare (Eton College Archives), Ed Copenhagen and his colleagues (Harvard University Archives), Julien Couture and Bozena Latincic (McGill University Archives), 
Jonathan Smith (Rugby School Archives), and Michael Frost, Bill Landis and Nancy F. Lyon (Yale University Archives). Finally, many thanks go to Professors Tony Collins, Rhodri Jeffreys-Jones and Jean Williams, along with the two anonymous manuscript reviewers and the journal's editors, for their valuable feedback on earlier drafts of this article. 